Nadwa | Jurnal Pendidikan Islam

Vol. 10, Nomor 2, Oktober 2016

\title{
Pengembangan Sumber Belajar Berbasis Karakter Peserta Didik (Ikhtiar optimalisasi Proses Pembelajaran Pendidi- kan Agama Islam (PAI))
}

\author{
M. Syahran Jailani \\ IAIN Sulthan Thaha Safuddin Jambi \\ Email: m.syahran@gmail.com
}

\author{
Abdul Hamid \\ STAIS An-Nadwah Kuala Tungkal, Jambi
}

\begin{abstract}
:
This article aims to reveal the theoretical academic studies in the context of learning resources as epicentrum valuable information for each individual study. This paper uses descriptive analytical method. The results of this study indicate that the source of learning was instrumental in providing a range of information and knowledge required to develop skills and competencies. The way to develop learning resources of Islamic education in order to optimally conducted by 1) analyzing the needs and characteristics of students' learning, 2) formulate learning objectives, 3) the development of learning material, 4) developing tools to measure the progress, 5) selection of learning resources and 6) hold evaluation.
\end{abstract}

Keywords: learning resources; islamic education; teacher

\begin{abstract}
Abstrak
Artikel ini bertujuan mengungkap secara teoritis kajian akademik dalam konteks sumber belajar sebagai epicentrum informasi yang berharga bagi setiap manusia yang belajar. Penulisan ini menggunakan metode deskriptif analitis. Hasil kajian ini menunjukkan bahwa sumber belajar sangat berperan dalam menyediakan berbagai informasi dan pengetahuan yang diperlukan dalam mengembangkan berbagai kompetensi yang diinginkan. Adapun cara mengembangkan sumber belajar Pendidikan Agama Islam agar optimal dilakukan dengan 1) menganalisis kebutuhan dan karakteristik belajar siswa, 2) merumuskan tujuan pembelajaran, 3) pengembangan materi pembelajaran, 4) mengembangkan alat ukur keberhasilan, 5) pemilihan jenis sumber belajar dan 6) mengadakan evaluasi.
\end{abstract}

Kata Kunci: sumber belajar; Pendidikan Agama Islam; Peserta didik

ISSN 1979-1739 (P) ; ISSN 2502-8057 (E)

(C) 2016 Nadwa|IAIN Walisongo

http://journal.walisongo.ac.id/index.php/nadwa 


\section{Pendahuluan}

Secara faktual ikhtiar pengembangan sumber belajar merupakan sebuah keniscayaan. Keniscayaan pengembangan sumber belajar didasarkan pada dua realitas berlawanan yang dimilikinya. Di mana di satu sisi sumber belajar memiliki sifat yang statis, akan tetapi di sisi lain dituntut memiliki peran yang dinamis. Sifat statis berasal dari komponen sumber belajar yang berupa benda meliputi; manusia, buku, perpustakaan, media massa, alam lingkungan, dan media pendidikan. Sedangkan dari sisi peran, sumber belajar dituntut untuk berperan sebagai sumber berbagai informasi dan pengetahuan yang diperlukan dalam mengembangkan berbagai kompetensi yang diinginkan pada bidang studi atau mata pelajaran yang dipelajarinya. Dengan kondisi tersebut maka sumber belajar sangat penting untuk dikembangkan dan terbarukan.

Salah satu cara pengembangan sumber belajar yang cukup prospektif adalah dengan berbasis peserta didik. Hal ini dikarenakan keberadaan sumber belajar selalu terkait bahkan tidak dapat dipisahkan dengan kondisi peserta didik. Sehingga pengembangan sumber belajar yang baik harus terintegrasi dengan realitas peserta didik. Dengan demikian pengembangan berbasis peserta didik menjadi salah satu cara pengembangan yang terintegrasi.

Pengembangan sumber belajar berbasis peserta didik memungkinkan tercapainya proses pembelajaran yang optimal. Pasalnya kualitas pembelajaran terkait erat dengan kualitas sumber belajarnya. Di mana proses pembelajaran yang baik akan membutuhkan pengembangan sumber belajar yang baik. Dengan kata lain sebuah proses pembelajaran tanpa pengembangan sumber belajar yang tepat maka tidak mungkin terlaksana dengan optimal. Dengan demikian pengembangan sumber belajar berbasis peserta didik memungkinkan dapat meningkatkan kualitas pembelajaran.

Prinsip umum dalam pengembangan sumber belajar berbasis peserta didik adalah efektifitas dan efesiensi. Prinsip efektifitas mengarah pada upaya pengembangan yang menghasilkan penghematan waktu, sedangkan efesiensi mengarah pada kemudahan teknis. Dengan kata lain prinsip pengembangan ini adalah mengarah kepada terciptanya sumber belajar yang dapat mempermudah dan mempercepat proses 
pembelajaran. ${ }^{1}$ Berdasarkan deskripsi diatas maka penulis tertarik membahas tema ini dengan sub bab sebagai berikut: Sumber Belajar dan Seluk Beluknya, Pengembangan Sumber Belajar Berbasis Karakteristik Peserta Didik..

\section{Sumber Belajar dan Seluk beluknya}

Mengingat definisi sumber belajar adalah segala sesuatu yang dapat dipergunakan sebagai tempat dimana bahan pengajaran terdapat atau asal untuk belajar seseorang. ${ }^{2}$ Dengan demikian segala sesuatu baik yang sengaja dirancang (by design) maupun yang telah tersedia (by utilization) yang dapat dimanfaatkan baik secara sendiri-sendiri maupun bersama-sama untuk membuat atau membantu peserta didik belajar disebut sumber belajar.

Proses komunikasi dalam dunia pendidikan tidak berbeda dengan proses pembelajaran kecuali pada aspek konteks berlangsungnya komunikasi Proses Belajar Mengajar (PBM). Dari berbagai sumber belajar yang ada dan mungkin didayagunakan dalam pembelajaran sedikitnya dapat dikelompokkan sebagai berikut:

1. Manusia (people), yaitu orang yang menyampaikan pesan pengajaran secara langsung; seperti guru, konselor administrasi, yang dirancang secara khusus dan disengaja untuk kepentingan belajar (by design). Di samping itu ada pula orang yang tidak diniati untuk kepentingan pembelajaran tetapi memiliki suatu keahlian yang bisa dimanfaatkan untuk kepentingan pembelajaran, misalnya penyuluh kesehatan, polisi, pemimpin perusahaan, dan pengurus koperasi. Orang-orang tersebut tidak dirancang, tetapi sewaktu-waktu bias dimanfaatkan untuk kepentingan pembelajaran (learning resources by utilization).

2. Bahan(material),yaitu sesuatu yang mengandung pesan pembelajaran; baik yang diniati secara khusus seperti film pendidikan, peta, grafik, buku paket, dan sebagainya, yang

${ }^{1}$ Hadari Nawawi, Pendidikan dalam Islam, (Surabaya: Al-Ikhlas, 1993), hal. 126.

${ }^{2}$ Aswan Zain dan Bahri Syaiful Djamarah, StrategiBelajarMengajar, (Jakarta: RinekaCipta, 1997), hal. 139 
biasanya disebut media pembelajaran (instruktional media), maupun bahan bersifat umum; seperti film dokumentasi

3. Lingkungan (setting), yaitu ruangan dan tempat ketika sumber-sumber data berinteraksi dengan para peserta didik. Ruangan dan tempat yang diniati secara sengaja untuk kepentingan pembelajaran, misalnya ruangan perpustakaan, ruangan kelas, laboratorium, dan rungan mikro teaching. Di samping itu ada pula ruangan dan tempat yang tidak rancang untuk kepentingan belajar, namun bisa dimanfaatkan; misalnya museum, kebun binatang, kebun raya, candi, dan tempat-tempat beribadat.

4. Aktivitas (activities), yaitu sumber belajar yang merupakan kombinasi antara suatu teknik dengan sumber lain untuk memudahkan (facilitates) belajar, misalnya pembelajaran berprogram merupakan kombinasi antara teknik penyajian bahan dengan buku; contoh lainnya seperti simulasi dan karyawisata.

5. Alat dan peralatan (tools and equipment), yaitu sumberbelajar untuk produksi dan memainkan sumber-sumber lain. Alat dan peralatan untuk produksi misalnya kamera untuk produksi foto, dan tape recorder untuk rekaman. Sedang alat dan peralatan yang digunakan untuk memainkan sumber lain, misalnya proyektor film, pesawat televisi, dan pesawat radio. ${ }^{3}$ Alat dan perlengkapan untuk produksi, reproduksi pameran, peragaan, simulasi dan sebagainya. Biasanya berbentuk peralatan seperti proyektor slide, overhead projector (OHP), proyektor film, computer, video, taperecorder, pesawat radio, pesawat televisi (TV), internet, dan sebagainya. ${ }^{4}$

Dilihat dari perancangannya, secara garis besar sumber belajar dapat dibedakan menjadi dua macam, yaitu:

1. Sumber belajar yang dirancang (learning resources by design) yakni sumber-sumber yang secara khusus dirancang atau dikembangkan sebagai komponen sistem instruksional

${ }^{3}$ E. Mulyasa, Menjadi Guru Profesional, (Bandung: Remaja Rosdakarya, 2008), hal. 177-178.

${ }^{4}$ Ramayulis, Metodologi Pendidikan Agama Islam, (Jakarta: Kalam Mulia, 2005), hal. 141. 
untuk memberikan fasilitas belajar yang terarah dan bersifat formal.

2. Sumber belajar yang dimanfaatkan (learning resources by utililization) yakni sumber belajar yang tidak didesain khusus untuk keperluan pembelajaran dan keberadaannya dapat ditemukan, diterapkan dan dimanfaatkan untuk keperluan pembelajaran. ${ }^{5}$

Sumber belajar yang dipakai dalam pendidikan atau latihan adalah suatu sistem yang terdiri dari sekumpulan bahan atau situasi yang diciptakan dengan sengaja dan dibuat agar memungkinkan siswa belajar secara individual. Sumber belajar seperti inilah yang disebut media pendidikan atau media instruksional. Sumber belajar yang cocok bagi siswa harus memenuhi tiga persyaratan harus dapat tersedia dengan cepat, harus memungkinkan siswa untuk memacu diri sendiri, harus bersifat individual, misalnya harus dapat memenuhi berbagai kebutuhan siswa. ${ }^{6}$

Perkembangan ilmu pengetahuan dan teknologi telah membawa perubahan yang sangat signifikan terhadap berbagai dimensi kehidupan manusia, baik dalam ekonomi, sosial, budaya maupun pendidikan saat ini. Oleh karena itu, agar pendidikan tidak tertinggal dari perkembangan IPTEK, maka kepala sekolah harus mengadakan penyesuaian-penyesuaian, terutama yang digunakan guru, sehingga mereka menyampaikan materi pelajaran kepada siswa secara baik berdaya guna dan berhasil guna. Jika hal ini tercapai, maka tujuan pendidikan dan pembelajaran tentunya tercapai pula.

Guru mempunyai tanggungjawab membantu peserta didik belajar agar belajar lebih mudah, lebih lancar, lebih terarah dengan pemanfaatan sumber belajar. Oleh sebab itu guru dituntut untuk memiliki kemampuan khusus yang berhubungan dengan pemanfaatan sumber belajar. Menurut Ditjend. Dikti, guru harus mampu : (a) menggunakan sumber belajar dalam kegiatan pembelajaran sehari-hari, (b) mengenalkan dan menyajikan sumber belajar, (c) menerangkan peranan berbagai sumber belajar dalam pembelajaran, (d) menyusun tugas-tugas

${ }^{5}$ Mohammad Ali, dkk (Edit), Ilmu dan Aplikasi Pendidikan, (Bandung: Pedagogiana Press, 2007), hal. 544.

${ }^{6}$ Fred Parcival dan Henry Ellington, Teknologi Pendidikan, Terjemahan Soedjarwo S, (Jakarta: Erlangga, 1988), hal. 125. 
penggunaan sumber belajar dalam bentuk tingkah laku, (e) mencari sendiri bahan dari berbagai sumber, (f) memilih bahan sesuai dengan prinsip dan teori belajar, (g) menilai keefektifan penggunaan sumber belajar sebagai bagian dari bahan pembelajaran, (h) merencanakan kegiatan penggunaan sumber belajar secara efektif. ${ }^{7}$

Penggunaan sumber belajar janganlah sekedar dianggap sebagai upaya membantu guru yang bersifat pasif, artinya penggunaannya semata-mata ditentukan oleh guru. Melainkan membantu anak didik untuk belajar, kalau perlu dengan cara individual artinya anak dapat berinteraksi secara individual dengan media dan secara kelompok sesama teman di kelas. Beberapa pertimbangan dalam pemilihan media dalam pembelajaran, yaitu:

1. Ketersediaan sumber tempat, artinya bila media yang bersangkutan tidak terdapat pada sumber-sumber yang adamakaharus dibeli atau dibuat sendiri.

2. Untuk membeli ataumemproduksi sendiri telah tersedia dana dan tenaga.

3. Faktor yang menyangkut keluwesan, kepraktisan dan ketahanan media yang digunakan untuk jangka waktu yang lama, artinya bila digunakan dimanasaja dengan peralatan yang ada di sekitarnya dan kapanpun serta mudah dibawa.

4. Efektivitas dan efesiensi biaya dalam jangka waktu yang cukup panjang, sekalipun nampak mahal namun mungkin lebih murah dibanding media lainnya yang hanyadapat digunakan sekali pakai. ${ }^{8}$

\section{Pengembangan Sumber Belajar Berbasis Karakteristik Peserta Didik}

Secara historis penggunaan sumber belajar dalam dunia pendidikan sudah dikenal sejak lama. Bila menoleh sejarah pendidikan di kalangan umat Islam, maka pada zaman pertengahan Islam fasilitas sumber belajar sudah dikenal walupun amat sederhana namun sudah dilengkapi adanya ruangan yang luas untuk tempat perkuliahan, sudah ada asrama

${ }^{7}$ Depdikbud, Teknologi Instruksional, (Jakarta: Ditjen Dikti, , 1983), hal. 38-39.

${ }^{8}$ Aswan Zain dan Bahri Syaiful Djamarah, op. cit.., hal. 126. 
untuk mahasiswa, juga ada rumah-rumah pengajar, dilengkapi pula dengan tempat-tempat rekreasi, kamar mandi, dapur, dan ruang makan. ${ }^{9}$

Saat ini trend penggunaan sumber belajar tidak hanya digunakan apa adanya melainkan dikembangkan terlebih dahulu. Salah satu cara yang dapat dilakukan dalam pengembangan sumber belajar adalah dengan merencanakan langkah-langkah secara sistematis. Adapun langkah-langkah sistemstis dalam pengembangan sumber belajar diantaranya adalah :

1. Menganalisis Kebutuhan dan Karakteristik Belajar Siswa

Jika membuat program sumber belajar tentu yang diharapkan dari program yang dibuat akan digunakan atau dimanfaatkan oleh siswa. Program tersebut hanya akan digunakan kalau program itu memang mereka perlukan. Sebagai perancang program siswa, tentu guru harus dapat mengetahui pengetahuan dan keterampilan awal siswa. Suatu program sumber belajar akan dianggap terlalu mudah bagi siswa bila siswa tersebut telah memiliki sebagian besar pengetahuan/keterampilan yang disajikan oleh program sumber belajar tersebut, begitu pula sebaliknya. ${ }^{10}$

Sebuah perencanaan sumber belajar didasarkan salah satu indikatornya di dalamnya terdapat kesenjangan. Kesenjangan adalah ketidaksesuaian antara apa yang seharusnya atau apa yang diharapkan dengan apa yang terjadi. Dalam pembelajaran yang dimaksud dengan kebutuhan adalah adanya kesenjangan antara kemampuan, keterampilan dan sikap siswa yang diinginkan dengan kemampuan, keterampilan dan sikap siswa yang mereka miliki sekarang. ${ }^{11}$

Sebagai sumber belajar yang meletakkan cara berpikir konkrit dalam kegiatan belajar mengajar,

${ }^{9}$ Muhammad Attiyah Al-Abrasyi, Dasar-Dasar Pokok Pendidikan Islam, Terj. Bustami A. Gani dan Djohar Bahry, (Jakarta: Bulan Bintang, 1974), hal. 82.

${ }^{10}$ Arief. S. Sadiman, Media Pendidikan, (Jakarta: Raja Grafindo Persada, 2005), hal. 101-103.

11 Bukittinggi news.com, "Desain Media Pembelajaran", (http://bukittingginews.com /2011/06/desain-media-pembelajaran/diakses 19 Agustus 2011), hal. 2. 
pengembangannya diserahkan kepada guru. Guru dapat mengembangkan sumber belajar sesuai dengan kemampuannya. Dalam hal ini akan terkait dengan kecermatan guru memahami kondisi psikologis siswa, tujuan metode, dan kelengkapan alat bantu. Kesesuaian dan keterpaduan dari semua unsur ini akan sangat mendukung pengembangan sumber belajar pengajaran.

2. Merumuskan Tujuan Pembelajaran

Kunci dalam rangka menentukan tujuan pembelajaran adalah kebutuhan siswa, mata pelajaran, dan guru itu sendiri. Berdasarkan kebutuhan siswa dapat ditetapkan apa yang hendak dicapai, dikembangkan dan diapresiasi. Berdasarkan mata ajaran yang ada dalam petunjuk kurikulum dapat ditentukan hasil-hasil pendidikan yang diinginkan. Suatu tujuan pembelajaran seyogianya memenuhi kriteria sebagai berikut:

a. Menyediakan situasi atau kondisi untuk belajar.

b. Mendefenisikan tingkah laku siswa dalam bentuk dapat diukur dan dapat diamati.

c. Menyatakan tingkat minimal perilaku yang dikehendaki. $^{12}$

Mager, dikutip Hamalik ${ }^{13}$, merumuskan konsep tujuan pembelajaran yang menitik beratkan pada tingkah laku siswa dan perbuatan (performance) sebagai output (keluaran) pada diri siswa, yang dapat diamati. Output tersebut menjadi petunjuk, bahwa siswa telah telah melakukan kegiatan belajar. Tujuan merupakan dasar untuk mengukur hasil pembelajaran, dan juga menjadi landasan untuk menentukan isi pelajaran dan metode mengajar.

Berdasarkan isi dan metode selanjutnya ditentukan kondisi-kondisi kegiatan pembelajaran yang terkait dengan tujuan tingkah laku tersebut, yang disebut sebagai kondisi internal. Kegiatan-kegiatan yang tidak terkait dengan tujuan tingkah laku disebut kondisi luar. Berdasarkan pemikiran ini, maka dianggap perlu menentukan kondisi-kondisi ekternal yang berguna untuk meyakinkan bahwa perilaku

${ }^{12}$ Oemar Hamalik, Kurikulum dan Pembelajaran, (Jakarta : Bumi Aksara, 2008), hal. 76-77.

${ }^{13}$ Ibid., hal. 77-78. 
yang diperoleh benar-benar disebabkan oleh kegiatan belajar, bukan karena sebab-sebab lainya. Sebagaimana firman Allah swt. "Dan tidak aku ciptakan jin dan manusia melainkan supaya mereka menyembah-Ku" (QS. 51: 56). ${ }^{14}$

Allah swt. sendiri menciptakan manusia memiliki tujuan tertentu, demikian pula dalam mengerjakan apapun, manusia perlu menentukan tujuan yang jelas. Langkahlangkah dalam pembelajaran perlu direncanakan agar tujuan pelajaran dapat tercapai, hal ini juga untuk mempermudah pemahaman peserta didik dalam memahami materi yang sedang diajarkan. Umumnya langkah-langkah membelajarkan didasarkan dari yang mudah ke yang sukar dan dari yang bersifat ingatan sampai ke evaluasi atau modifikasi. Dalam langkah membelajarkan perlu dianjurkan terlebih dahulu konsep dasar atau dasar teori sebelum memasuki pemecahan masalah.

Setelah melakukan identifikasi karakteristik siswa, guru perlu menerapkan tujuan pembelajaran atau kompetensi yang harus dicapai, meliputi aspek kognitif, efektif, dan psikomotor. Tujuan pembelajaran yang dirumuskan dapat dijadikan sebagai pedoman untuk memiliki metode, sumber belajar, dan strategis pembelajaran yang akan digunakan. Ketiga komponen ini perlu di aplikasikan dalam menyelenggarakan proses pembelajaran. Keterlibatan siswa secara aktif dalam proses belajaran akan memberikan kontibusi positif bagi terciptakan proses belajar yang optimal. Evaluasi perlu dilakukan untuk mengetahui pencapaian kompetensi atau tujuan pembelajaran. ${ }^{15}$

Desain pembelajaran untuk jangka waktu yang singkat adalah sebagai berikut:

a. Setiap guru harus merumuskan tujuan instruksional yang akan diajarkan.

b. Guru harus menguasai materi pelajaran yang akan diberikan kepada siswa.

${ }^{14}$ Departemen Agama RI, op. cit., hal. 862.

${ }^{15}$ Benny A. Pribadi, Model Desain Sistem Pembelajaran, (Jakarta: Dian Rakyat, 2010), hal. 186-187. 
c. Seorang guru harus memiliki banyak sumber-sumber belajar.

d. Seorang guru harus banyak menguasai sistem pengajaran.

e. Seorang guru harus mampu memanfaatkan sumber belajar pendidikan yang ada secara tepat.

f. Seorang guru harus mengetahui assesmen siswa.

g. Setiap guru merencanakan kegiatan selama proses pembelajaran.

h. Guru harus menguasai pengertian, tujuan dan teknik evaluasi dengan baik.

i. Setiap guru selalu berusaha mengembangkan segala komponen yang berfungsi dan berinteraksi di dalam sistem pengajaran itu.

j. Perencanaan yang dibuat, merupakan antisipasi dan perkiraan tentang apa yang akan dilakukan dalam pengajaran, sehingga tercipta suatu situasi yang memungkinkan terjadinya proes belajar yang dapat mengantarkan siswa mencapai tujuan yang diharapkan. ${ }^{16}$

Pada hakekatnya jika suatu kegiatan direncanakan terlebih dahulu, keberhasilan atau kelancaran menuju tujuan yang akan dicapai akan lebih terarah. Hal itulah yang membuat para guru harus memiliki kemampuan untuk membuat sebuah desain sumber belajar yang kreatif. Seorang guru hendaknya merencanakan program pembelajaran yang berupa materi maupun keterampilan yang akan diberikan setiap pertemuannya. Desain pembelajaran itu dapat sebagai kontrol dan pegangan saat membelajarkan bagi guru itu sendiri.

3. Pengembangan Materi Pembelajaran

Sebelum memasuki kelas, kita harus meracang tentang apa yang mesti disampaikan kepada siswa sesuai dengan tujuan pembelajaran yang hendak dicapai, dan pengalaman belajar siswa nantinya mengandung muatan pelajaran, muatan pelajaran mencakup kebutuhan siswa itu sendiri. Muatan pelajaran adalah materi yang disusun oleh guru atau tenaga

\footnotetext{
hal. 45-47.

${ }^{16}$ Roestiyah NK, Masalah Pengajaran, (Jakarta: Rineka Cipta, 1994),
} 
pengajar, yang diambil dari sumber utama dan sumber penunjang.

Materi disusun berdasarkan tujuan, kompetensi dan indikator belajar yang telah dikembangkan sebelumnya. Kesesuaian materi yang dikemas dengan tujuan, kompetensi dan indikator merupakan jaminan bagi tercapainya hasil belajar yang diharapkan, demikian juga sebaliknya, bila materi disusun tidak merujuk ketujuan, kompetensi dan indikator, maka akan menjauh kan dari capaian hasil belajar yang optimal. ${ }^{17}$

Di dalam pengembangan materi, alat dan sumber berupa buku pelajaran yang dipergunakan sebagai rujukan harus disesuaikan dengan kurikulum. Muatan pelajaran biasanya selalu berubah-ubah karena diperkaya dengan informasi komplek. Maka kita sebagai guru boleh-boleh saja mempergunakan buku tambahan lain dan harus diberitahukan kepada siswa. Materi atau bahan pembelajaran merupakan bagian terpenting bagi terlaksananya proses pembelajaran, yang tertuang kedalam kurikulum yang harus dikuasai oleh guru dan peserta didik. $^{18}$

Untuk dapat mengembangkan bahan instruksional yang mendukung tercapainya tujuan pembelajaran, tujuan yang telah dirumuskan harus dianalisis lebih lanjut. Kepada setiap tujuan itu pertanyaan yang sama diajukan yaitu kemampuan yang harus dimiliki siswa sebelum siswa memiliki kemampuan yang dituntut tujuan khusus ini. ${ }^{19}$

Alat pengukur keberhasilan dapat berupa tes, penguasaan atau daftar cek perilaku. Alat pengukur keberhasilan perlu dikembangkan dengan berpijak pada tujuan yang telah dirumuskan dan harus sesuai dengan materi yang telah disiapkan. Yang perlu diukur adalan tiga kemampuan utama, yaitu pengetahuan, sikap/ perilaku dan

${ }^{17}$ Mukhtar dan Iskandar, Desain Pembelajaran Berbasis Teknologi Informasi dan Komunikasi (Sebuah Orientasi Baru),(Jakarta: Gaung Persada Press, 2010),hal. 44-45.

${ }^{18}$ Ibid.,hal. 45.

${ }^{19}$ Arief. S. Sadiman, op. cit., hal. 111-112. 
keterampilan. Dengan demikian terdapat hubungan yang erat antara tujuan, materi dan tes pengukur keberhasilan. ${ }^{20}$

Dengan membuat pertanyaan-pertanyaan ini, maka guru bisa menentukan materi pelajaran yang diberikan kepada siswa, disertai pemilihan sumber belajar yang yang tepat.

4. Mengembangkan Alat Ukur Keberhasilan

Alat pengukur keberhasilan siswa perlu didirancang sebelum naskah program sumber belajar ditulis atau sebelum kegiatan belajar mengajar dilaksanakan. Alat ini dapat berupa tes, penugasan atau daftar cek perilaku. Alat pengukur keberhasilan harus dikembangkan sesuai dengan tujuan yang akan dicapai dan pokok-pokok materi pelajaran yang akan disajikan kepada siswa. ${ }^{21}$ Alat pengukur keberhasilan harus bisa digunakan secara tepat saat dibutuhkan dalam pembelajaran, dengan alat pengukur keberhasilan ini bisa dilihat keberhasilan siswa belajar dengan menggunakan sumber belajar yang ada.

5. Pemilihan Jenis Sumber Belajar

Sumber belajar dalam proses pembelajaran mempunyai arti yang cukup penting karena ketidakjelasan bahan yang disampaikan dapat dibantu dengan menghadirkan sumber belajar sebagai perantara. Kerumitan bahan yang akan disampaikan kepada anak didik dapat disederhanakan dengan bantuan sumber belajar. Sumber belajar dapat mewakili apa yang kurang mampu diucapkan oleh guru dengan kata-kata atau kalimat tertentu, dan dengan demikian anak didik lebih mudah mencerna bahan yang dipelajarinya.

Kegunaan sumber belajar dalam proses pembelajaran adalah sebagai berikut:

1) Memperjelas penyajian pesan agar tidak terlalu bersifat verbalistis (dalam bentuk kata-kata tertulis atau lisan belaka).

2) Mengatasi keterbatasan ruang, waktu dan daya indera.

\footnotetext{
${ }^{20}$ Bukittinggi news.com, "Desain Media Pembelajaran", hal. 3.

${ }^{21}$ Arief. S. Sadiman, op. cit., hal. 114.
} 
3) Dengan mengunakan sumber belajar pendidikan dengan cara tepat dan bervariasi dan dapat diatasi sikap pasif anak didik.

4) Dengan sifat yang unik pada siswa ditambah lagi dengan lingkungan dan pengalaman yang berbeda, sedangkan kurikulum dan pendidikan ditentukan sama untuk siswa maka guru akan banyak mengalami kesulitan bila mana semuanya itu diatasi sendiri. ${ }^{22}$

Setelah menentukan pilihan sumber belajar yang hendak digunakan, maka akhirnya guru dituntut untuk dapat memanfaatkannya dalam proses pembelajaran. Sumber belajar yang baik belum tentu menjamin keberhasilan belajar siswa jika guru tidak dapat menggunakannya dengan baik. Untuk itu, sumber belajar yang telah dipilih dengan tepat harus dapat dimanfaatkan dengan sebaik mungkin sesuai prinsip-prinsip pemanfaatan sumber belajar.

Sumber belajar mempunyai sifat menyalurkan pesan, merangsang kemauan siswa, maka seorang guru harus memiliki pengetahuan dan pemahaman yang cukup tentang sumber belajar yang digunakannya, meliputi:

a. Sumber belajar sebagai alat komunikasi guru lebih mengefektifkan proses belajar mengajar.

b. Sumber belajar berfungsi sebagai alat untuk mencapai tujuan pendidikan.

c. Penggunaan sumber belajar dalam proses belejar mengajar.

d. Hubungan antara metode pengajaran dengan sumber belajar pendidikan.

e. Nilai dan manfaat sumber belajar pendidikan.

f. Memilih dan menggunakan sumber belajar pendidikan.

g. Mengetahui sebagai jenis alat dan teknik sumber belajar pendidikan.

h. Mengetahui penggunaan sumber belajar pendidikan dalam setiap mata pelajaran yang diajarkan.

22 Sardiman AM, Interaksi dan Motivasi Belajar Mengajar, (Surabaya: Usaha Nasional, 2003), hal. 16. 
i. Melakukan usaha-usaha inovasi dalam sumber belajar pendidikan. $^{23}$

Berdasarkan hal di atas bahwa sumber belajar pendidikan sangat tepat untuk membantu upaya mencapai keberhasilan proses pendidikan dan pengajaran di sekolah. Oleh karena itu, guru harus mempunyai keterampilan dalam memilih dan menggunakan sumber belajar pendidikan dan pengajaran. Sumber belajar sebagai alat bantu dalam proses pembelajaran merupakan kenyataan yang tidak dapat dipungkiri, karena memang gurulah yang menghendakinya untuk membantu tugas guru dalam menyampaikan pesanpesan dari bahan pelajaran yang diberikan guru kepada anak didik. Guru sadar bahwa tanpa bantuan sumber belajar maka bahan pengajaran sukar untuk dicerna dan dipahami oleh setiap anak didik, terutama bahan pengajaran yang rumit atau kompleks.

Sumber belajar mempunyai fungsi melicinkan jalan menuju tercapainya tujuan pengajaran. Hal ini dilandasi dengan keyakinan bahwa proses belajar mengajar dengan bantuan sumber belajar mempertinggi kegiatan belajar anak didik yang akan menghasilkan proses dan hasil belajar yang lebih baik dari pada tanpa bantuan sumber belajar. ${ }^{24}$

Menurut pendapat yang lain dikatakan bahwa prinsipprinsip penggunaan sumber belajar pembelajaran adalah sebagai berikut:

a. Penggunaan sumber belajar hendaknya dipandang sebagai bagian integral dari suatu sistem pengajaran.

b. Sumber belajar pengejaran hendaknya di pandang sebagai sumber belajar yang digunakan dalam usaha memecahkan masalah yang dihadapi dalam proses belajar mengajar.

c. Guru hendaknya benar-benar menguasai teknik-teknik dari suatu sumber belajar pengajaran yang digunakan.

d. Guru seharusnya memperhitungkan untung ruginya pemanfaatan suatu sumber belajar pengajaran.

${ }^{23}$ Basyiruddin Usman dan Asnawir, Media Pembelajaran,(Jakarta: Delia Citra Utama, 2005), hal. 18.

${ }^{24}$ Syaiful Bahri Djamarah dan Aswan Zain, op. cit., hal. 138. 
e. Penggunaan sumber belajar pengajaran harus diorganisir secara sistematis.

f. Memanfaatkan multi sumber belajar jika hal itu diperlukan. ${ }^{25}$

Dalam menggunakan sumber belajar hendaknya guru memperhatikan sejumlah prinsip tertentu agar penggunaan sumber belajar tersebut dapat mencapai hasil yang baik. Prinsip-prinsip itu menurut Sudjana, dikutip Djamarah adalah 1) Menentukan sumber belajar dengan tep at; artinya, sebaiknya guru memilih terlebih dahulu sumber belajar manakah yang sesuai dengan tujuan dan bahan pelajaran yang akan diajarkan, 2) Menetapkan atau memperhitungkan subjek dengan tepat; artinya, perlu diperhitungkan apakah penggunaan sumber belajar itu sesuai dengan tingkat kematangan/kemampuan anak didik, 3) Menyajikan sumber belajar dengan tepat; artinya, tekhnik dan metode penggunaan sumber belajar dalam pengajaran haruslah disesuaikan dengan tujuan, bahan metode, waktu, dan sarana yang ada, 4) Menempatkan atau memperlihatkan sumber belajar pada waktu, tempat dan situasi yang tepat; artinya, kapan dan dalam situasi mana pada waktu mengajar sumber belajar digunakan. Tentu tidak setiap saat atau selama proses belajar mengajar terus menerus memperlihatkan atau menjelaskan sesuatu dengan sumber belajar pengajaran. ${ }^{26}$

Perkembangan ilmu pengetahuan dan teknologi semakin mendorong upaya-upaya pembaharuan dalam pemanfaatan hasil-hasil teknologi dalam proses belajar. Dalam hal ini perkembangan teknologi dapat dimanfaatkan atau digunakan sebagai sumber belajar maupun sumber belajar pembelajaran. Namun tak dapat dipungkiri bahwa banyak tenaga pendidik yang tidak bisa mengoperasikan atau mengggunakan peralatan teknologi saat ini. Sehingga saat ini sangat dituntut untuk dapat mengembangkan keterampilan dalam proses belajar mengajar agar tidak tertinggal.

Mendesain sumber belajar pendidikan menghendaki pemenuhan tuntutan zaman. Era teknologi saat ini menghendaki dunia

\footnotetext{
${ }^{25}$ Basyiruddin Usman dan Asnawir, op. cit.,hal. 19.

${ }^{26}$ Syaiful Bahri Djamarah dan Aswan Zain, op. cit., hal.143-145.
} 
pendidikan menyesuaikan diri, termasuk aspek sarana prasarana pendidikan yang berbasis teknologi. Teknologi telah menjadi fasilitator utama bagi kegiatan-kegiatan bisnis, memberikan andil besar terhadap perubahan-perubahan yang mendasar pada struktur operasi dan manajemen organisasi.

Secara garis besar, dapat dikatakan bahwa, 1) Teknologi menggantikan peranan manusia, dalam hal ini, teknologi informasi melakukan atomasi terhadap suaatu tugas atau proses, 2) Teknologi memperkuat peran manusia, yakni dengan menyajikan informasi terhadap suatu tugas dan 3) Teknologi informasi bertugas dalam resrukturisasi terhadap peran manusia. Dalam hal ini, teknologi berperan dalam melakukan perubahanperubahan terhadap sekumpulan tugas atau proses. ${ }^{27}$

Perkembangan ilmu pengetahuan dan teknologi semakin mendorong upaya-upaya pembaharuan dalam pemanfaatan hasil-hasil teknologi dalam proses pembelajaran, termasuk dalam pemilihan dan pengunaan sumber belajar pembelajaran. Para guru dituntut agar mampu menggunakan sumber belajar pendidikan yang disediakan sekolah yang sesuai dengan perkembangan dan tuntutan zaman dan kepala sekolah harus bijaksana menyediakan sumber belajar pendidikan yang dibutuhkan guru dalam pembelajaran.

6. Mengadakan Evaluasi

Pembelajaran merupakan totalitas aktivitas belajar dan membelajarkan yang diawali dengan desain pembelajaran diakhiri dengan evaluasi. Dari evaluasi ini diteruskan dengan follow up. Dengan demikian desain pembelajaran pembelajaran adalah suatu pemikiran atau persiapan untuk melaksanankan tugas aktivitas pengajaran dengan menerapkan prinsip-prinsip pengajaran serta melalui langkah-langkah pengajaran.

Evaluasi adalah proses memberikan atau menentukan terhadap hasil belajar tertentu berdasarkan suatu kriteria tertentu. ${ }^{28}$ "Evaluasi merupakan suatu proses untuk menentukan jasa, nilai, atau manfaat kegiatan pembelajaran

${ }^{27}$ Abdul Kadir, Pengenalan Sistem Informasi, (Yogyakarta: Andi Offset, 2003), hal. 15.

${ }^{28}$ Asep Jihad dan Abdul Haris, Evaluasi Pembelajaran, (Yogyakarta: Multi Pressindo, 2008), hal. 55. 
melalui kegiatan penilaian dan pengukuran." 29 Evaluasi sumber belajar adalah proses yang dimaksudkan untuk mengumpulkan data tentang efektivitas dan efisiensi bahanbahan pelajaran, termasuk sumber belajar. ${ }^{30}$

\section{Kesimpulan}

Sumber belajar berperan dalam menyediakan berbagai informasi dan pengetahuan yang diperlukan dalam mengembangkan berbagai kompetensi yang diinginkan pada mata pelajaran yang dipelajarinya. Mengembangkan sumber belajar Pendidikan Agama Islam dilakukan dengan 1) menganalisis kebutuhan dan karakteristik belajar siswa, 2) merumuskan tujuan pembelajaran, 3) pengembangan materi pembelajaran, 4) mengembangkan alat ukur keberhasilan, 5) pemilihan jenis sumber belajardan 6) mengadakan evaluasi.

\section{DaftarPustaka}

Al-Abrasyi, Muhammad Attiyah, 1974. Dasar-Dasar PokokPendidikan Islam, Terj. Bustami A. Gani dan Djohar Bahry, Jakarta: Bulan Bintang.

Ali, Mohammad, dkk (Edit), 2007. Ilmu dan Aplikasi Pendidikan, Bandung: Pedagogiana Press.

Basyiruddin Usman dan Asnawir, 2005. Media Pembelajaran,Jakarta: Delia Citra Utama.

Bukittingginews.com, "Desain Media Pembelajaran", (http://bukittingginews.com /2011/06/desain-mediapembelajaran/diakses 19 Agustus 2011.

Depag RI, 1994. Al-Qur'an dan Terjemahnya, Jakarta: Depag RI.

Depdikbud, 1983. Teknologi Instruksional, Jakarta: Ditjen Dikti. Hamalik, Oemar, 2008. Kurikulum dan Pembelajaran, Jakarta : Bumi Aksara.

Jihad,Asep dan Abdul Haris, 2008. Evaluasi Pembelajaran, Yogyakarta: Multi Pressindo.

${ }^{29}$ Mukhtar, Evaluasi yang Sukses Pedoman Mengukur Kinerja Pembelajaran, (Jakarta: Sasana Mitra Suksesa, 2003), hal. 59

${ }^{30}$ Arief. S. Sadiman, op. cit., hal. $182 .$. 
Kadir, Abdul, 2003. Pengenalan Sistem Informasi, Yogyakarta: Andi Offset.

Mukhtar dan Iskandar, 2010. Desain Pembelajaran Berbasis Teknologi Informasi dan Komunikasi,Jakarta: Gaung Persada Press.

Mukhtar, 2003. Evaluasi yang Sukses Pedoman Mengukur Kinerja Pembelajaran, Jakarta: Sasana Mitra Suksesa.

Mulyasa, E., 2008. Menjadi Guru Profesional, Bandung: Remaja Rosdakarya.

Nawawi, Hadari, 1993. Pendidikan dalam Islam, Surabaya: AlIkhlas.

Parcival, Fred dan Henry Ellington, 1988. Teknologi Pendidikan, Terjemahan Soedjarwo S, Jakarta: Erlangga.

Pribadi, Benny A., 2010. Model Desain Sistem Pembelajaran, Jakarta: Dian Rakyat.

Ramayulis, 2005. Metodologi Pendidikan Agama Islam, Jakarta: Kalam Mulia.

Roestiyah NK, Masalah Pengajaran, Jakarta: Rineka Cipta, 1994.

Sadiman, Arief. S., 2005. Media Pendidikan,Jakarta: Raja Grafindo Persada.

Sardiman AM, 2005. Interaksi dan Motivasi Belajar Mengajar, Jakarta: Raja Grafindo Persada.

Zain, Aswan dan Bahri Syaiful Djamarah, 1997. Strategi BelajarMengajar, Jakarta: Rineka Cipta. 